\title{
Diversity and Abundance of Birds of Prey and Owls in Four selected Areas in South Western Nigeria
}

\author{
Okosodo E.F., Orimaye J. O., Odewumi O.S
}

\begin{abstract}
${ }^{1}$ Department of Ecotourism and Wildlife Management, Federal University of Technology, PMB 1054, Akure, Ondo State Nigeria
${ }^{2}$ Forestry, Wildlife and Fisheries Management Department, Ekiti State University Ado-Ekiti, Ekiti State Nigeria

${ }^{3}$ Department of Ecotourism and Wildlife Management, Federal University of Technology, PMB 1054, Akure, Ondo State Nigeria
\end{abstract}

\begin{abstract}
This study examined the birds of prey and owls diversity and abundance in four selected areas South Western Nigeria. The study was carried out in two agro ecological zones, LFCW and OOYP in the guinea savanna zone and ONP and IFR in the rain forest agro ecological zone. A total of 120 counting stations were used and 30stations per each study site. Counting bands of $50 \mathrm{~m}$ radius were used for all the stations..Thirty nine bird species belonging to three families were recorded in the in the four study areas. Black Kite has the highest number of individual species while, the Hooded Vulture and Tawny Eagle have the lowest individual species. The diversity index was higher in the Dry season than the Wet season. Rare species of owls were recorded in LFCW and ONP.
\end{abstract}

Keywords-Prey, Owls, LFCW, OOYP, ONP, IFR.

\section{INTRODUCTION}

Birds in their diversity constitute part of the natural environment and play functional roles such as agents of flower pollination and seed dispersal, sources of food chain and agents in breaking seed dormancy. Otieno, (2009) reported that birds are highly specialized flying machines, and their ability to fly allows them to cover a wide range in search of food and escape predators easily. Estimates of bird's abundance are widely used in bird conservation. For example, they allow us to measure changes in population size (Newton, 1979) and to assess whether isolated populations are workable(Frank, et al, 2005).Information on population sizes of individual species can also be used to set priorities, allowing conservation effort to be focused on those species most in need of attention (Mijele, . 2009). Birds usually select foraging habitats based on the availability of their main prey items and understanding habitat preferences provides critical information for species conservation (Houston,1974).
Birds of prey or raptors are among the most vulnerable taxa to environmental disturbance (Newton 1979). Consequently, their presence has been often cited as indicative for the biological diversity of the ecosystems on which they depend, since top predators select such sites, promote ecosystem diversity by top-down predation, or provide essential resources, such as carrion for scavengers (Sergio et al. 2006, 2008). As raptors are relatively easily observed top predators, they are among the most useful higher taxa to evaluate the state of the environment over wide areas in open to semi-open areas, including savannas. Raptors are an important tool to focus conservation strategies locally, regionally, and globally (Watson1991).

They can be used as "umbrella species" because their large home ranges and low densities necessitate that any protected areas encompassing viable populations or complete communities protect sufficient habitat and populations of most, if not all, other species in the food (Thiollay 1992). Because of their top positions in terrestrial and aquatic food webs, raptors can be used as indicators of worldwide pollution by pesticides (Newton1979). Changes in raptor distribution or abundance can serve as a measure of our impact on landscapes, even in remote areas (Pain,et al,3003). Raptors are popular and charismatic and several species have become significant "flagships" for increasing public interest and support of conservation programs (Thiollay 1992). Raptors exhibit physical adaptations that make them highly efficient predators. For example, raptors are generally light in weight, yet powerful for their size. Sharp talons (or claws) and sharp, hooked beaks suit the raptors' carnivorous lifestyle. 


\section{II.}

\section{MATERIALS AND METHODS}

Study Area

Four study areas in two agro ecological zones were used for this research study.Leventis Foundation Conserved Woodland (LFCW) and Old Oyo National Park (OONP) are in guinea savanna zone while Okomu National Park (ONP) and Idanre Forest Reserve (IFR) are in the rain forest agro ecological zone.The Leventis Foundation Conserved Woodland is privately owned and is located west of River Niger at the coordinate of 6.41E and 7. 7.N The size of the area is 70 square kilometer and Idanre Forest Reserve has a total land area of $527.1 \mathrm{~km} 2$, although official compartment maps estimate an area of $540.45 \mathrm{~km} 2$ with coordinates of $6^{\circ} 51^{\prime 2} 28^{\prime \prime} \mathrm{N} \mathrm{5} 06^{\prime} 20^{\prime \prime} \mathrm{E}$ (Isichei, 1995,Ikemeh, 2009). Okomu National Park is located in Ovia Southwest Local Government Area of Edo State Nigeria, the park became a full-fledged National Park through the provision of Decree 46 of 1999.The park covers a total land area of $181 \mathrm{~km}^{2}$, which is only about $15 \%$ of the total land area that was then Okomu Forest Reserve, which covered a total land area $1200 \mathrm{~km}^{2}$ (White, and Oates, 1999).It has central coordinates of $5.267^{\circ} \mathrm{E}$ and $6.33^{\circ}$. Old Oyo National Park is one of the national parks in Nigeria, located across northern Oyo State and southern Kwara State, Nigeria. The park has total land mass of $2,512 \mathrm{~km}^{2}$ and is located in south west park of Nigeria, specifically northern Oyo State at latitude $8^{\circ} 15^{\text {, }}$ and $9^{\circ} 00^{\prime} \mathrm{N}$ and longitude $3^{\circ} 35^{\prime}$ and $4^{\circ} 42^{\prime} \mathrm{E}$ (Oladeji, et al, 2012).

The southwestern Nigeria environment comprises of the lowland rainforest, stretching from the coast to about $50 \mathrm{~km}$ inland in it western boundary near the Dahomy Gap, to about $150 \mathrm{~km}$ inland around the region of the Kukuruku hills and further stretching to the western bank of Niger River as it eastern boundary. Rainfall is usually between 1,500-2,500 $\mathrm{mm}$ and capable of sustaining the rainforest environment under natural condition, distributed over $8-9$ month period (March - October/November) and depending largely on the distance from the coast. In the times past, vegetation in the zone falls within the lowland rainforest (Keay, 1989, Ogunjemite and Oates 2008). However, the present physiognomic component of the environment, particularly in region of Kukuruku Hills, is mainly that of forest/savanna mosaic. The southern parts still have large, continuous patches of reserved forests that had been variously degraded as a result of timber exploitation and encroachment for farming. The impacts of human activities have contributed seriously to the degraded value of the forest environment.

Data collection
Data were collected for six months three months in the dry season (November, February and March) and three months in the wet season (June, August and September) in 2015. The "Timed Species Count (TSC)" method developed by(Pomeroy and Tengecho, 1989) was used for assessing the diversity and abundance of species of raptors inthe study sites. Counting stations or predefined spots were established in roosting sites, wetland and feeding sites as well as forest edges. Counting bands of $50 \mathrm{~m}$ radius was used for all the stations. The minimum distance between two counting stations was $200 \mathrm{~m}$. The number of counting stations was determined by the site size. In all 120 counting station were used, 30 stations per a study site.

On arrival at the sites birds were allowed time to settle before recording all the birds seen or heard for a predetermined time.(20 minutes). Bird calls were also recorded with a voice recorder and played back later for confirmation. Physical features of birds sighted but could not be identified immediately were taken and field guide book of West African birds (Burrow and Demey, 2011) was used to identify the bird species and bird calls was used to confirmed the presence of nocturnal bird species within the study sites.

From the data collected, avian species diversity was calculated using Shannon diversity index, (Usher, 1991) which is given as:

$\mathrm{H}^{\mathrm{i}}=-\Sigma \mathrm{Pi}$ In Pi

Where: $\mathrm{H}^{\mathrm{i}}=$ diversity index

$\mathrm{Pi}=$ is the proportion of the ith species in the sample

$\mathrm{InPi}=$ is the natural logarithm of the species proportion.

Species Relative Population Density

The relative population density of bird species at various sites and seasons were determined as outlined by Bibbyet al.,(1992) as follows:

$\mathrm{D}=\underline{\mathrm{n}}_{1} \frac{+\mathrm{n}_{2}}{\pi \mathrm{r}^{2} \mathrm{~m}} \log _{\mathrm{e}}\left[\mathrm{n}_{1} \underline{\mathrm{n}_{2}}\right]$

where: $\mathrm{D}=$ density

$r=$ radius of the first zone

$\mathrm{n} 1=$ number of birds counted within zone

$\mathrm{n} 2=$ number of birds counted beyond zone and $\mathrm{m}=$ number of replicate count in such area.

Data collected from the observations were explored with descriptive statistics and analyzed with analysis of variance (ANOVA) using the Statistical Package for Social Sciences (SPSS) version 17 (SPSS, 2008). 


\section{RESULTS}

Thirty nine (39) bird of prey and owls belonging to three family were encountered in the four study areas, the family Accipitridae has the highest bird species which constituted $66.7 \%$ of the bird species observed in the four study areas (Figure 1). A total of 229 bird species were enumerated, Black kite has highest of individual species of (32) observed in the four study areas while Hooded vulture and Tawny Eagle have lowest number of individual species observed in the four study areas (Table 1). In LFCW Hooded Vulture (Necrosyrtesmonachus) an endangered bird species was observed in the study area. Also observed in this study area are two migrants Martial Eagle (Polemaetusbellicosus ), Twany Eagle (Aquila rapax ) and a rare species of owl
Vermiculated Fishing Owl (Scotopeliabouvieri). In ONP and IFR the birds of prey encountered were that of Forest species, examples of such species are Chestnut FlankedSparrowhawk (Accipiter castanilius), Long Tailed Hawk (Urotriorchismacrourus) and RedThinghedSparrowhawk (Accipitererythropus). In ONP we encountered three rare species of Owl theFrasser's Eagle Owl (Bubo poensis), Greyish Vermiculated Eagle Owl (Bubo africanus) and Shelley's Eagle Owl (Bubo shelleyi). All the birds of prey encountered in OYNP were savanna bird species. The Black Kite occurred in the four study areas (Table 2).Diversity index of birdspecies in the four study areas showed in Table 3 and 4

Table 1: Coporative Total Count of Bird Species in the Four Study Areas

\begin{tabular}{|c|c|c|c|c|c|c|}
\hline Common Name & Scientific Name & LFCW & ONP & IFR & OYNP & \\
\hline African Cuckoo Hawk & Avicedacuculoides & 4 & _- & 3 & 5 & 12 \\
\hline African Fish Eagle & Haliaeetusvocifer & 2 & 3 & 2 & 4 & 11 \\
\hline African Goshawk & Accipiter tachiro & 3 & - & & 2 & 5 \\
\hline African Harrier Hawk & Polyboroidestypus & 4 & 3 & 6 & 5 & 18 \\
\hline African Hawk Eagle & Polyboroidestypus & 1 & _ & _ & 2 & 3 \\
\hline African Hobby & Falco cuveierii & 3 & - & - & 2 & 5 \\
\hline African Marsh Harrier & Circusranivorus & 4 & _ & _ & 1 & 5 \\
\hline African Wood Owl & Strixwoodfordii & 3 & 6 & 4 & 2 & 15 \\
\hline Barn Owl & Tyto alba & 2 & - & - & 3 & 5 \\
\hline Bat Hawk & Macheiramphusalcinus & 3 & _ & - & 1 & 4 \\
\hline Black Kite & Milvusmigrans & 9 & 6 & 4 & 13 & 32 \\
\hline Black Shouldered Kite & Black Shouldered Kite & 5 & - & - & 2 & 7 \\
\hline Black Sparrowhawk & Accipiter melanoleucus & 2 & _- & - & 1 & 3 \\
\hline Brown Snake Eagle & Circaetuscinerascens & 3 & - & - & 2 & 5 \\
\hline Cassin's Hawk Eagle & Spizaetusafricanus & - & 4 & 3 & - & 7 \\
\hline Chestnut Flanked Sparrowhawk & Accipiter castanilius & - & 3 & 1 & - & 4 \\
\hline Common Kestrel & Falco tinnunculus & 5 & - & - & 3 & 8 \\
\hline Crown Eagle & Stepphanoaetuscoronotus & 2 & - & _- & 1 & 3 \\
\hline Dark Chanting Goshawk & Melieraxmetabates & 3 & 2 & - & 2 & 7 \\
\hline Frasser's Eagle Owl & Bubo poensis & _ & _ & _ & & \\
\hline Grey Kestrel & Falco ardosiaceus & 4 & - & - & 2 & 6 \\
\hline $\begin{array}{l}\text { Greyish Vermiculated Eagle } \\
\text { Owl }\end{array}$ & Bubo africanuscinerascens & & 2 & - & - & 2 \\
\hline Hooeded Vulture & Necrosyrtesmonachus & 1 & - & - & - & 1 \\
\hline Lanner Falcon & Falco biarmicus & 4 & _- & _- & 2 & 6 \\
\hline Little Sparrowawk & Accipiter minullus & 5 & _- & - & & 5 \\
\hline
\end{tabular}




\begin{tabular}{ccccccc}
\hline Lizard Burzard & Kaupifalcomonogrammicus & 5 & 7 & 3 & 7 & 22 \\
Long Crested Eagle & Lophaetusoccipitalis & - & 3 & - & 1 & 4 \\
Long Tailed Hawk & Urotriorchismacrourus & - & 1 & - & - & 1 \\
Martial Eagle & Polemaetusbellicosus & 3 & - & - & - & 3 \\
Northern White-Faced Owl & Ptilopsisleucotis & 4 & - & - & 6 & 10 \\
Palm -Nut Vulture & Gypohieraxangolensis & - & 7 & 8 & 9 & 24 \\
Red Neck Burzard & Buteoauguralis & 2 & - & - & 3 & 5 \\
Red Neck Falcon & Falco chiquera & 2 & - & - & 1 & 3 \\
Red ThghedSparowhawk & Accipitererythropus & - & - & 2 & - & 2 \\
Saker Falcon & Falco cherrug & 2 & - & - & - & 2 \\
Shelley's Eagle Owl & Bubo shelleyi & - & 2 & 1 & & 3 \\
Shikra & Accipiter badius & 2 & - & - & 5 & 7 \\
Tawny Eagle & Aquila rapax & 3 & - & - & - & 3 \\
Vermiculated Fishing Owl & Scotopeliabouvieri & 1 & - & - & - & 1 \\
& & 96 & 49 & 37 & 87 & 269
\end{tabular}

Table 2: Bird Species Encountered in each Study area

\begin{tabular}{cccccc}
\hline Common Names & Scientific Name & LFCW & ONP & IFR & OYNP \\
\hline African Cuckoo Hawk & Avicedacuculoides & $\sqrt{ }$ & $\times$ & $\sqrt{ }$ & $\sqrt{ }$ \\
African Fish Eagle & Haliaeetusvocifer & $\sqrt{ }$ & $\sqrt{ }$ & $\times$ & $\sqrt{ }$ \\
African Goshawk & Accipiter tachiro & $\sqrt{ }$ & $\times$ & $\times$ & $\sqrt{ }$ \\
African Harrier Hawk & Polyboroidestypus & $\sqrt{ }$ & $\sqrt{ }$ & $\sqrt{ }$ & $\sqrt{ }$ \\
African Hawk Eagle & Polyboroidestypus & $\sqrt{ }$ & $\times$ & $\times$ & $\times$ \\
African Hobby & Falco cuveierii & $\sqrt{ }$ & $\times$ & $\times$ & $\sqrt{ }$ \\
African Marsh Harrier & Circusranivorus & $\sqrt{ }$ & $\times$ & $\times$ & $\sqrt{ }$ \\
African Wood Owl & Strixwoodfordii & $\sqrt{ }$ & $\sqrt{ }$ & $\sqrt{ }$ & $\sqrt{ }$ \\
Barn Owl & Tyto alba & $\sqrt{ }$ & $\times$ & $\times$ & $\sqrt{ }$ \\
Bat Hawk & Macheiramphusalcinus & $\sqrt{ }$ & $\times$ & $\times$ & $\sqrt{ }$ \\
Black Kite & Milvusmigrans & $\sqrt{ }$ & $\sqrt{ }$ & $\sqrt{ }$ & $\sqrt{ }$ \\
& & & & & $\sqrt{ }$ \\
Black Shouldered Kite & Black Shouldered Kite & $\sqrt{ }$ & $\times$ & $\times$ & \\
Black Sparrowhawk & Accipiter melanoleucus & $\sqrt{ }$ & $\times$ & $\times$ & $\sqrt{ }$ \\
Brown Snake Eagle & Circaetuscinerascens & $\sqrt{ }$ & $\times$ & $\times$ & $\sqrt{ }$ \\
Cassin's Hawk Eagle & Spizaetusafricanus & $\times$ & $\sqrt{ }$ & $\sqrt{ }$ & $\times$ \\
Chestnut Flanked Sparrowhawk & Accipiter castanilius & $\times$ & $\sqrt{ }$ & $\times$ & $\times$ \\
Common Kestrel & Falco tinnunculus & $\sqrt{ }$ & $\times$ & $\times$ & $\sqrt{ }$ \\
Crown Eagle & Stepphanoaetuscoronotus & $\sqrt{ }$ & $\times$ & $\times$ & $\sqrt{ }$ \\
Dark Chanting Goshawk & Melieraxmetabates & $\sqrt{ }$ & $\times$ & $\times$ & $\sqrt{ }$ \\
Frasser's Eagle Owl & Bubo poensis & $\times$ & $\sqrt{ }$ & $\times$ & $\times$ \\
\hline & & & &
\end{tabular}




\begin{tabular}{cccccc}
\hline Grey Kestrel & Falco ardosiaceus & $\sqrt{ }$ & $\times$ & $\times$ & $\sqrt{ }$ \\
Greyish Vermiculated Eagle Owl & Bubo africanuscinerascens & $\times$ & $\sqrt{ }$ & $\sqrt{ }$ & $\times$ \\
Hooeded Vulture & Necrosyrtesmonachus & $\sqrt{ }$ & $\times$ & $\times$ & $\times$ \\
Lanner Falcon & Falco biarmicus & $\sqrt{ }$ & $\times$ & $\times$ & $\sqrt{ }$ \\
Little Sparrowawk & Accipiter minullus & & $\times$ & $\times$ & $\sqrt{ }$ \\
Lizard Burzard & Kaupifalcomonogrammicus & $\sqrt{ }$ & $\sqrt{ }$ & $\sqrt{ }$ & $\sqrt{ }$ \\
Long Crested Eagle & Lophaetusoccipitalis & $\sqrt{ }$ & $\sqrt{ }$ & $\sqrt{ }$ & $\sqrt{ }$ \\
Long Tailed Hawk & Urotriorchismacrourus & $\times$ & $\sqrt{ }$ & $\sqrt{ }$ & $\times$ \\
Martial Eagle & Polemaetusbellicosus & $\sqrt{ }$ & $\times$ & $\times$ & $\times$ \\
Northern White-Faced Owl & Ptilopsisleucotis & $\sqrt{ }$ & $\times$ & $\times$ & $\sqrt{ }$ \\
Palm -Nut Vulture & Gypohieraxangolensis & $\times$ & $\sqrt{ }$ & $\sqrt{ }$ & $\sqrt{ }$ \\
Red Neck Burzard & Buteoauguralis & $\sqrt{ }$ & $\times$ & $\times$ & $\sqrt{ }$ \\
Red Neck Falcon & Falco chiquera & $\sqrt{ }$ & $\times$ & $\sqrt{ }$ & $\sqrt{ }$ \\
Red ThghedSparowhawk & Accipitererythropus & $\sqrt{ }$ & $\times$ & $\times$ & $\sqrt{ }$ \\
Saker Falcon & Falco cherrug & $\times$ & $\times$ & $\times$ & $\times$ \\
Shelley's Eagle Owl & Bubo shelleyi & $\times$ & $\sqrt{ }$ & $\times$ & $\times$ \\
Shikra & Accipiter badius & $\sqrt{ }$ & $\times$ & $\times$ & $\sqrt{ }$ \\
Tawny Eagle & Aquila rapax & $\sqrt{ }$ & $\times$ & $\times$ & $\times$ \\
Vermiculated Fishing Owl & Scotopeliabouvieri & $\sqrt{ }$ & $\times$ & $\times$ & $\times$ \\
\hline
\end{tabular}

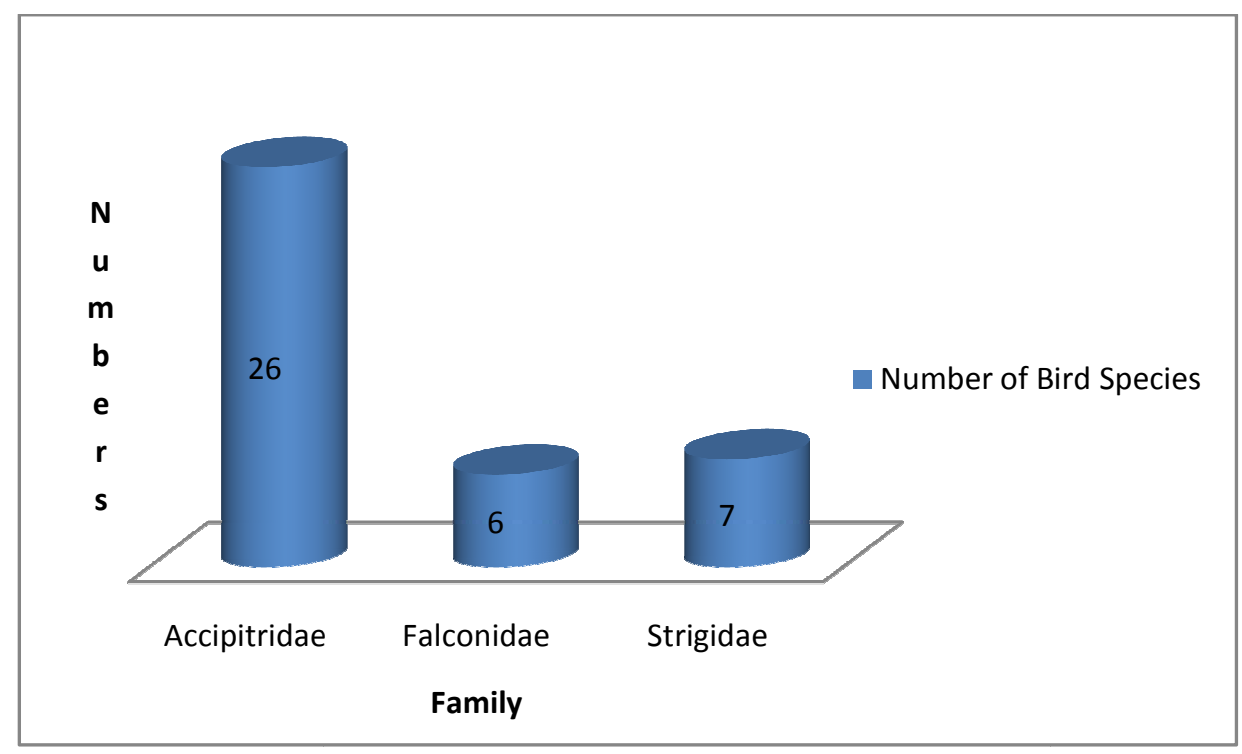

Fig.1: Bird Species Family composition in in the Four Study Areas 
Table 3: Avian Species Diversity Index in Four Study Areas during the Dry season

\begin{tabular}{|c|c|c|c|c|c|c|c|c|c|c|c|c|}
\hline $\begin{array}{l}\text { Diversity } \\
\text { Index }\end{array}$ & $\begin{array}{l}\text { LFC } \\
W\end{array}$ & Lower & Upper & ONP & $\begin{array}{l}\text { Lowe } \\
\mathbf{r}\end{array}$ & $\begin{array}{l}\text { Uppe } \\
\mathbf{r}\end{array}$ & IFR & $\begin{array}{l}\text { Lowe } \\
\mathbf{r}\end{array}$ & $\begin{array}{l}\text { Uppe } \\
\mathbf{r}\end{array}$ & OONp & Lower & Upper \\
\hline Taxa_S & 26 & 25 & 26 & 11 & 10 & 11 & 9 & 8 & 9 & 26 & 25 & 26 \\
\hline Individuals & 97 & 97 & 97 & 40 & 40 & 40 & 32 & 32 & 32 & 97 & 97 & 97 \\
\hline \multirow[t]{2}{*}{ Dominance_D } & 0.0419 & 0.0449 & 0.0577 & 0.112 & 0.105 & 0.176 & 0.127 & 0.123 & 0.197 & 0.0419 & 0.0449 & 0.0577 \\
\hline & 8 & 6 & 1 & 5 & & 2 & & & 3 & 8 & 6 & 1 \\
\hline \multirow[t]{2}{*}{ Simpson_1-D } & 0.958 & 0.9423 & 0.955 & 0.887 & 0.823 & 0.895 & 0.873 & 0.802 & 0.877 & 0.958 & 0.9423 & 0.955 \\
\hline & & & & 5 & 7 & & & 7 & & & & \\
\hline Evenness_e^ ${ }^{\wedge} \mathbf{H}$ & 0.955 & 0.7972 & 0.9169 & 0.900 & 0.703 & 0.928 & 0.930 & 0.738 & 0.948 & 0.955 & 0.7974 & 0.9173 \\
\hline$/ \mathbf{S}$ & & & & 8 & 1 & 5 & 8 & 7 & 2 & & & \\
\hline Margalef & 5.465 & 5.246 & 5.465 & 2.711 & 2.44 & 2.711 & 2.308 & 2.02 & 2.308 & 5.465 & 5.246 & 5.465 \\
\hline \multirow[t]{2}{*}{ Equitability_J } & 0.9859 & 0.9304 & 0.9733 & 0.956 & 0.851 & 0.968 & 0.967 & 0.858 & 0.975 & 0.9859 & 0.9304 & 0.9735 \\
\hline & & & & 4 & 7 & 2 & 4 & 9 & 8 & & & \\
\hline Chao-1 & 26 & 25.5 & 31 & 11 & 10 & 14 & 9 & 8 & 12 & 26 & 25.6 & 31 \\
\hline
\end{tabular}

Table Avian Species Diversity Index in Four Study Areas during the Wet season

LFCW Lower Upper ONP Lower Upper IFR Lower Upper OOYP Lower Upper

\begin{tabular}{cccccccccccccc}
\hline Taxa_S & 21 & 20 & 21 & 11 & 9 & 11 & 9 & 7 & 9 & 21 & 20 & 21 \\
Individuals & 62 & 62 & 62 & 29 & 29 & 29 & 28 & 28 & 28 & 62 & 62 & 62 \\
& & & & & & & & & & & & \\
Dominance_D & 0.06296 & 0.05931 & 0.09365 & 0.1153 & 0.1058 & 0.1843 & 0.1301 & 0.125 & 0.2066 & 0.06296 & 0.05931 & 0.09313 \\
Simpson_1-D & 0.937 & 0.9063 & 0.9407 & 0.8847 & 0.8133 & 0.8942 & 0.8699 & 0.7934 & 0.875 & 0.937 & 0.9069 & 0.9407 \\
Evenness_e^H/S & 0.8665 & 0.7067 & 0.8852 & 0.8786 & 0.6984 & 0.9152 & 0.9139 & 0.7252 & 0.9396 & 0.8665 & 0.7066 & 0.8861 \\
Margalef & 4.846 & 4.604 & 4.846 & 2.97 & 2.376 & 2.97 & 2.401 & 1.801 & 2.401 & 4.846 & 4.604 & 4.846 \\
Equitability_J & 0.953 & 0.8852 & 0.9598 & 0.946 & 0.8472 & 0.9631 & 0.959 & 0.8516 & 0.9713 & 0.953 & 0.8857 & 0.9603 \\
Chao-1 & 21.38 & 20.75 & 33 & 11.1 & 9.25 & 21 & 9 & 7.5 & 15 & 21.38 & 20.75 & 31.5
\end{tabular}

\section{DISCUSSION}

The research study revealed that four study areas support diverse birds of prey and owls. The result obtained from research study indicates abundant birds of prey and owls were encountered in the study areas in the guinea savanna areas LFCW and OONP. The differences in bird species diversity and abundance in the different land use types may be due to land use changes and forest heterogeneity which bring about variation in the availability of food, cover, predation risk and micro -climatic variation which is supported by Cody (1985) who reported that the level of distribution of bird species in habitat is normally as a result of an occurrence of plant species that support their population and to variation in species-specific requirements in the choice of habitat. This is also consistent with Mangnall and Crowe, (2003) stated that the distribution of bird species is largely dependent on the availability of food, 
water and cover. Different groups of bird species seem to respond differently to different land uses. Insectivores are known to be an indicator of noticeable responses to land use. The number of migrant visitors to the forest agro ecological zone is lower than those migrant bird species utilizing the savanna agro ecological zone. ONP and IFR has one migrant bird species, while LFCW and OOYP has (5) migrant birds of prey. This finding is in consistent with Keith et al (1992) who reported that most migratory bird species frequent open savanna woodland where they forages mainly on the ground for insects millipedes, centipedes, spider, snails, earthworms and seeds.

The total number of migrant's bird species have declined when comparing the previous work of other researchers. Tucker and Evans (1977) reported that the populations of migratory birds that breed in temperate regions and winter in the tropics have suffered sustained and often severe declines over the past few decades. One recent analysis of continent-wide survey data from the Birds in Europe database (Tucker and Evans 1997, BirdLife International 2004) for the period between 1970 and 2000 has highlighted this decline. Truck and Evans (1997), suggested that combination of threats including habitat degradation on breeding grounds in Europe, hunting in southern Europe and North Africa and the loss of staging areas is likely to be influencing the declines. There is also some evidence that reduced over-winter survival in dry, open habitats in subSaharan Africa may be a contributing this factor. Habitat destruction, desertification and lower resource availability in the Sahel zone due to reduced rainfall and increased agricultural intensification may explain these lower overwinter survival rates

two rest blocks, and this suggest that human disturbance in populated areas alters bird species richness (Pearson, 1977), as they avoid predation. Similarly, Herkert (2009) reported that the loss of habitat to urbanization reduces the quality of the remaining vegetation thus affect the population of avian species in the area.Avian behavioral pattern was found to play a big role in bird diversity and distribution among the four areas sampled (Cody 1985). For example, Martial Eagle, Tawny Eagle Lanner Falcon,SakerFalcon (Falco cherrug ) and Crown Snake Eagle were sighted only in the LFCW and OONP in the guinea savanna area while Long Tailed Eagle, Chestnut Flanked Sparrowhawk,Frasser owl Eagle, andGreyish Vermiculated Eagle Owl were restricted to Forest agro ecological zone.

\section{CONCLUSION AND RECOMMENDATION}

Bird species diversity were higher in the guinea savanna agro ecological zone than in the farmland and forest agro ecological zone which suggests that birds of prey prefer open savanna area than forest zone.

The poaching of raptors, deforestation and agricultural expansion is presently ongoing in the four study sites. The four study areas is surrounded by large settlements and the people in the area are involved in logging, majorly cutting down commercial timber species such as Ceibapentandra, AlstoniacongensisColagigantea, Daniellaogea, these are tree species of conservation value. Selective logging of tree species in this area should be properly managed so that avian habitats can be supported. Land conversion for agricultural purposes is very high in this region, since most of the communities are agrarian. However, this may increase extinction risk for many threatened and endangered birds in the area, such asAquila rapax,Scotopeliabouvieri, GypohieraxangolensisLophaetuso ccipitalisand Falcobiarmicus. The management of these areas should design programmes to discourage bush burning, livestock grazing, deforestation and illegal farming in the forest area.

\section{REFERENCES}

[1] Cody, M.,L.,(1985) An introduction in habitat selection in birds. In Habitat selection in birds (Cody ed.) Academic Press Inc., London pp 191-248.

[2] Borrow, Nik and Demey Ron. (20012). "A guide to the birds of western Africa". Princeton University Press

[3] BirdLife International. (2004) State of the world's birds. Indicators for our changing world.

[4] Frank, L.G., R. Woodroffe, And M.O. Ogada. 2005. People and predators in Laikipia District, Kenya. Pages 286-304 in R. Woodroffe, S. Thirgood, and A. Rabinowitz [EDS.], People and Houston, D.C. wildlife: conflict or coexistence? Cambridge University Press, Cambridge, U.K.

[5] Herkert, J.R. (2009) Response of bird populations to farmland set-aside programs. Conservation Biology 23: $1036-1040$

[6] 1974. Food searching behaviour in Griffon Vultures. East African Wildlife Journal 12:63-77

[7] Keay.R.W.J.,(1989), Trees of Nigeria. A review version of Nigerian trees $(1960,1964)$ by R. W. J Keay, C. F. AOnochie and D. P Strandfield. Claridon Press Oxford University press: Pp 476 pp. 
[8] Keith,S., Urban,E.K. and Fry,C.H. (1992).The Birds of Africa Volume IV.London Academic Press.

[9] MacArthur R. H. and MacArthur J. W. (1999).On bird species diversity.Ecology 42, 594 - 598.

[10] Mangnall M.J. \& Crowe T.M. (2003) Theeffecte of agriculture on farmland bird assemblage on the Agulhas plain, Western Cape, South Africa. African journal of Ecology 41, 266-276

[11] Mengistu, and Salami . (2007). Application of remote sensing and GIS inland use/land cover mapping and change detection in a part of south western Nigeria. African Journal of Environmental Science and Technology Vol. 1 (5), pp. 099 -109.

[12] Mijele, D. 2009. Incidences Of Poisoning Of Vultures And Lions In The Masai Mara National Reserve.Kenya Wildlife Service Masai Mara Veterinary Report.Nairobi, Kenya

[13] Newton, I. 1979. Population Ecology Of Raptors. T. And A.D. Poyser, London, U.K.

[14] Oladeji, S. O, Agbelusi E, A and Trevelyan , R (2012). Anthropogenic activities threatening the Management of the Ecotourism resources in Old Oyo National Park, Nigeria.Ethopian Journal of Environmental Studies and Management Vol 5. No 1, pp. 100-111

[15] Otieno, P.O. 2009. Monitoring carbofuran residues in Laikipia and Isiolo districts in Kenya for ecological risk assessment. M.S. thesis, Department of Chemistry, Maseno University, Maseno, Kenya

[16]Pain, D.J., A.A. Cunningham, P.F. Donald, J.W. Duckworth, D.C. Houston, T. Katzner, J. Parry-Jones, C. Poole, V. Prakash, P. Round, And R. Timmins. 2003. Causes and effects of temporospatial declines of Gyps vultures in Asia. Conservation Biology 17:661671

[17]Pomeroy D.; BC Tengecho.Journal of Tropical Ecology, 1989, 2: 231-237.

[18] Pearson D. (1977) Pantropical comparison of bird community: structure of six lowland forest sites, Condor 79: 232-244.

[19] Sekercioglu, C.H. 2006. Increasing Awareness Of Avian Ecological Function. Trends In Ecology And Evolution 21:464-471

[20] Thiollay, J.M. 2006. The decline of raptors in West Africa: long-term assessment and the role of protected areas. Ibis 148:240-254

[21] Tucker, G.M., Evans, M.I. (1997) Habitats for birds in Europe: a conservation strategy for the wider environment. BirdLife Conservation Series No. 6. Cambridge: BirdLife International Turner, M.G.
(2005) Landscape ecology: What is the state of the science? Annual Review of Ecology Evolution and Systematics 36: 319-44.

[22] Usher, M.B. (1986) Wildlife Conservation evaluation: attributes, criteria and values. Wildlife Conservation Evaluation (Ed M.B. Usher).Chapman and Hall.3-44. 